\title{
The shaping of a species: the Azorian Drouetia Gude (Pulmonata: Zonitidae: Oxychilus) as a model
}

\author{
António M. de Frias Martins \\ CIRN and Departamento de Biologia, Universidade dos Açores, \\ 9501-801 Ponta Delgada, Portugal \\ E.mail: frias@notes.uac.pt
}

\begin{abstract}
The endemic Azorian zonitid subgenus Drouetia Gude, 1911 is spread throughout the archipelago and shows a wide range of variability. The spatial distribution of the Azores islands and their geomorphological history provide a privileged research ground to assess the interactions of isolation and time on the emergence of those variability patterns and thus to infer on the speciation process. Special attention is given to volcanic activity as a disturbing factor of the populational integrity.

From the observed patterns of distribution of intra- and interspecific shell morphology and anatomical variability in Drouetia the following speciation scenario may be advanced: Stage one: demic (allotopic) variability; it is postulated that volcanic instability (frequent cyclic eruptions) and intense erosion (deep ravines) create temporary isolates that (?200 yrs) later merge into a larger, genetically richer population. Stage two: close syntopic (interspecific) variability; it is postulated that short-term $(>2,000 \mathrm{ys})$ volcanic stability contributes to consummate speciation. Stage three: extreme syntopic (interspecific) variability; it is postulated that long-term volcanic stability ( $>1$ Mys) leads to supra-specific differentiation.
\end{abstract}

Key words: Droutia, morphology, anatomy, speciation, volcanic activity, Azores.

\section{INTRODUCTION}

Speciation is a multifaceted process leading to the separation of a parcel of a previously wider gene pool and culminating in its reproductive isolation (Mayr, 1977; Howard and Berlocher, 1998). From molecules to the individuals that carry them to the populations they live within, variability and selection, isolation and genetic drift, led by the patient hand of time, interact differently at each of these levels to produce the genetic oddities we call species. The road to speciation usually shows different grades of definition of such interaction. Notwithstanding the basic molecular nature of change - the very stuff of evolution - morphology is its readily visible face and may constitute a rough indicator of the speciation event. Consequently, although wanting validation through molecular methods of deeper resolution and being cautious about the plastic/genetic nature of the characters in use, analysis of the patterns of morphology distribution may point first hand to the framework of the process (Jenner, 2004; Wiens, 2004).

Spread throughout the archipelago and apparently free from visible biotic pressure, the endemic zonitids of the subgenus Drouetia Gude, 1911 provide a suitable model to study aspects of this process and the Azores constitute an adequate laboratory to research it (Martins 1993, 1995, 1998, 1999; Riedel, 1997). The geographical position and distribution of the islands, their different ages and the rhythmicity of the volcanic events that originated them provide an adequate scenario in which various stages of speciation can be found, thus allowing for extrapolations about the process.

\section{MATERIALS AND METHODS}

Specimens were collected from the islands of Santa Maria, São Miguel, Graciosa and Flores, and 22 stations were selected for this study (Figure 1; Table 1). The shells and reproductive systems were drawn with a camera lucida under a Wild M8 dissecting microscope and the various shell parameters (Figure 2) were quantified from the drawings. At least three specimens in each station were dissected and only a qualitative approach was attempted for the anatomy. The internal morphology of the penial complex was also prepared for SEM (Jeol JSM 5410) with aid of drying using hexamethyldisilane $(10 \mathrm{~min}$ at each of the following steps: $95 \%$ alcohol; absolute alcohol; 1:1 absolute alcohol/acetone; acetone; hexamethyldisilane). Prior to SEM examination, the 


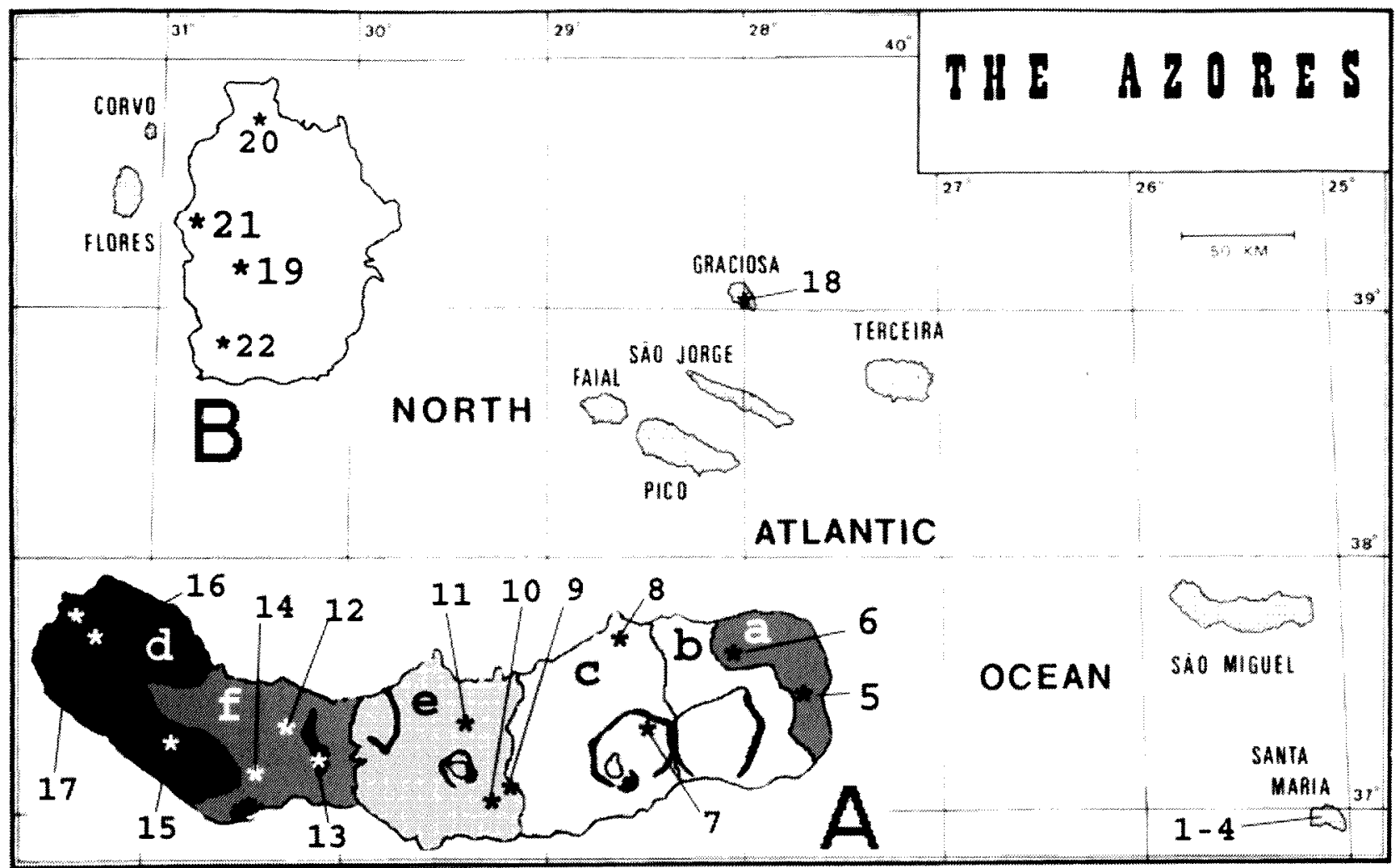

Figure 1 The archipelago of the Azores and the distribution of the collecting stations $\left({ }^{*} 1-22\right.$; see Table 1 for decoding). A. Inset showing São Miguel, representing the location of the stations and the geological history of the island: a, Nordeste; b, Povoação; c, Furnas; d, Sete Cidades; e, Fogo; f, Picos (adapted from Forjaz, 1984 and Nunes et al., 1993). B. Insert showing the location of the stations in Flores. Detail of the location of the stations in Santa Maria was not required for the scope of this study.

Table 1 List of the stations from where the material was collected.

\begin{tabular}{|c|c|}
\hline $\begin{array}{l}\text { Island/ } \\
\text { Station }\end{array}$ & Observations \\
\hline \multicolumn{2}{|l|}{ Santa Maria } \\
\hline 1 & Pico Alto, Santa Maria. $1974 ; 12-06-1990 ; 21-10-1993$. \\
\hline 2 & Terras do Raposo, Santa Maria. 13-06-1990. \\
\hline 3 & Santa Bárbara, Santa Maria. 22-10-1993. \\
\hline 4 & Panasco, Santa Maria. 16-06-1990. \\
\hline \multicolumn{2}{|l|}{ São Miguel } \\
\hline 5 & Ribeira do Tosquiado, S. Miguel. 03-08-1989. \\
\hline 6 & Algarvia, S. Miguel. 01-12-1996. \\
\hline 7 & Cumieira, Pedras do Galego, Furnas, S. Miguel. 15-03-1989 [7a]; 03-08-1989 [7b]. \\
\hline 8 & Ribeira dos Carneiros, Ribeira Funda, S. Miguel. 20-03-1989 [8a]; 06-08-1989 [8b]. \\
\hline 9 & Rosário, Pico do Vento, Vila Franca do Campo, S. Miguel. 23-09-1970. \\
\hline 10 & Queimada, Pico do Vento, Água d'Alto, S. Miguel. 21-09-1974. \\
\hline 11 & Caldeira Velha, Ribeira Grande, S. Miguel. 06-12-1989. \\
\hline 12 & Batalha, S. Vicente Ferreira, S. Miguel. 26-02-2004. \\
\hline 13 & Pico do Fogo, Livramento, S. Miguel. 06-03-1984 [13a]; 26-07-1989 [13b]. \\
\hline 14 & Abelheira, Fajã de Baixo, S. Miguel. 27-02-1988. [14a]; 26-07-1989 [14b]. \\
\hline 15 & Curral da Achada, Covoada, S. Miguel. 10-04-1988. \\
\hline 16 & Túnel, Sete Cidades, São Miguel. 20-06-1989. \\
\hline 17 & Ramal dos Mosteiros, S. Miguel. 13-05-1992. \\
\hline \multicolumn{2}{|l|}{ Graciosa } \\
\hline 18 & Pedras Brancas, Graciosa. 09-06-1988. \\
\hline \multicolumn{2}{|l|}{ Flores } \\
\hline 19 & Laranjeiro, Fajãzinha, Flores. 06-07-1989. \\
\hline 20 & Ponta Delgada, Flores. 07-07-1989. \\
\hline 21 & Ribeira da Casas, Fajã Grande, Flores. 05-07-1989. \\
\hline 22 & Terra Nova, Flores. 05-07-1989. \\
\hline
\end{tabular}



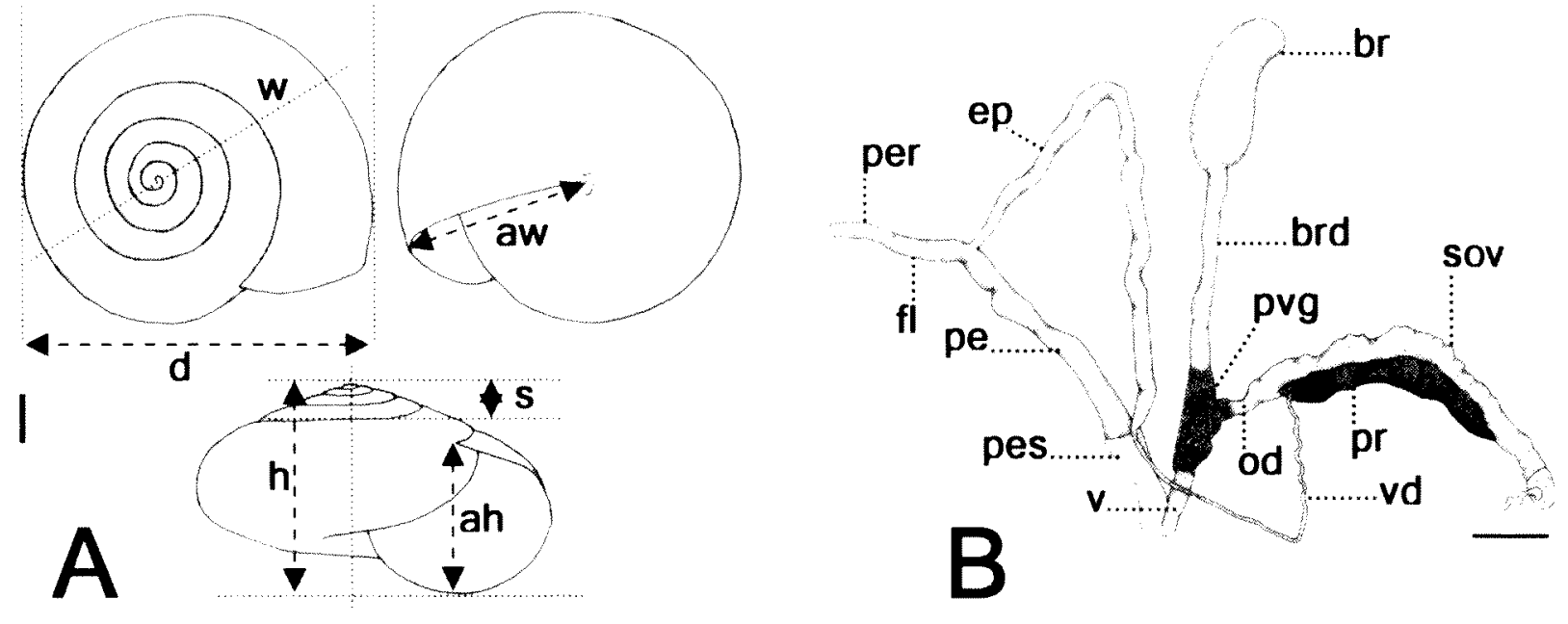

Figure 2 A. Shell of Oxychilus (Drouetia) atlanticus showing the morphometric parameters used in the analyses. B. Reproductive system of Oxychilus (Drouetia) atlanticus illustrating the terminology used in the text. Scale lines $=1 \mathrm{~mm}$. Abbreviations: ah, height of the aperture; aw, width of the aperture; br, bursa; brd, bursa duct; $d$, diameter of the shell; ep, epiphallus; $f$, flagellum; $h$, height of the shell; od, oviduct; pe, penis; per, penial retractor muscle; pes, penial sheath; pr, prostate gland; pvg, perivaginal gland; s, spire; sov, spermoviduct; $v$, vagina; $v d$, vas deferens; $w$, number of whorls.

samples were covered with gold/palladium $40 / 60$ in a vacuum evaporator Jeol JEE 400.

Canonical analysis was performed on the shell parameters and dendrograms obtained utilizing cluster analysis based on euclidean distance (UPGMA).

\section{The Azores}

The Azores (Figure 1) are subaereal tips of the Mid-Atlantic Ridge and are located about 1,600 km east of continental Europe (Portugal). The archipelago comprises nine volcanic islands spread throughout $600 \mathrm{~km}$ along a NW-SE axis, arranged in three groups: Eastern Group (São Miguel and Santa Maria), Central Group (Terceira, Graciosa, São Jorge, Pico and Faial) and Western Group (Flores and Corvo). In this study, only four of the nine islands will be mentioned concerning their volcanic history; their changes after human colonization (about 500 years ago) are assumed to have no bearing in the speciation events here analysed.

Santa Maria $\left(97 \mathrm{~km}^{2}\right)$ is the southernmost and the oldest island (about $8 \mathrm{Mys}$ ); subaereal volcanic activity has ceased there since about 3 Mys (Serralheiro and Madeira, 1993). It has fossil beds of marine as well as of terrestrial origin, the latter being very rare.

The island of S. Miguel, eight times larger than Santa Maria and about $60 \mathrm{~km}$ north, has a wellstudied geo-morphological history (Booth et al., 1977; Moore, 1990; Moore and Rubin, 1991). The eastern tip of the island, Nordeste (a), is now an extinct volcano about 4 Mys old (Nunes et al., 1993; see Figure 1 , inset $A$, for explanation of the lettering $a-f)$; the complex of Povoação (b), now an extinct and partially eroded caldera, was added to it $2 \mathrm{Mys}$ ago; about 0.75 Mys ago the complex of Furnas (c) was formed. A new island appeared 0.5 Mys ago on what is now the Sete Cidades complex (d). The first island continued to grow westward with the addition of the Fogo complex (e) about 0.25 Mys ago and the two islands were united about 0.05 Mys ago through the Picos region (f). Volcanic activity has been intense in São Miguel; for Furnas alone (c), Queiroz et al. (1995) reported 10 eruptions for the period between the years 5000 B.P. and A.D. 1630 . On the basis of the events of the last three thousand years, a schedule of cyclic eruptions of the main centers has been proposed by Moore and Rubin (1991): 320 years for Furnas (c), 400 years for Sete Cidades (d), 1,150 years for Fogo (e) and 145 years for Picos region (f). The intensity of the eruptions and the spread of their products have also been recorded. Booth et al. (1977) made a quantitative survey of the volcanic activity in São Miguel over the past five thousand years and Walker and Croasdale (1971) presented a detailed history of two main events at the Fogo volcano, 4,600 years B.P. and A.D. 1563, thus allowing for extrapolations on how could it have affected the local biota.

Graciosa, a small $\left(67 \mathrm{~km}^{2}\right)$ and shallow $(402 \mathrm{~m})$ island, is probably not older than 600,000 years (Feraud et al., 1980); its volcanic history has been studied by Gaspar (1996). After the highly explosive events of Serra Branca, 350,000 years ago, most of the subsequent volcanism was effusive. Graciosa has had volcanic activity until about 2,000 years ago.

Flores, the westernmost island, is $143 \mathrm{~km}^{2}$. Its 
Table 2 Basic statistics (N, number of specimens; R, range; SD, standard deviation; X, mean) of shell morphometry of specimens of Oxychilus (Drouetia) from São Miguel (Sta 5-17) and from Flores (Sta 19-22) (see also Table 1). Variables: ah, aperture height; aw, aperture width; $d$, diameter of the shell; $h$, height of the shell; s, height of the spire; $w$, number of whorls.

\begin{tabular}{|c|c|c|c|c|c|c|c|c|c|c|c|c|c|c|c|c|c|c|c|}
\hline \multirow[t]{2}{*}{ Sta } & \multirow[t]{2}{*}{$\mathbf{N}$} & \multicolumn{3}{|c|}{$\mathbf{w}$} & \multicolumn{3}{|c|}{ d } & \multicolumn{3}{|c|}{$\mathbf{h}$} & \multicolumn{3}{|c|}{ aw } & \multicolumn{3}{|c|}{ ah } & \multicolumn{3}{|c|}{$\mathbf{s}$} \\
\hline & & $\mathbf{R}$ & $x$ & SD & $\mathbf{R}$ & $\bar{x}$ & SD & $\mathbf{R}$ & $\mathrm{x}$ & SD & $\mathbf{R}$ & $x$ & SD & $\mathbf{R}$ & $X$ & SD & $\mathbf{R}$ & $x$ & SD \\
\hline \multicolumn{20}{|c|}{ São Miguel } \\
\hline 5 & 16 & $5.1-5.8$ & 5.5 & 0.22 & $6.7-8.1$ & 7.4 & 0.45 & $3.7-4.7$ & 4.1 & 0.35 & $3.7-4.4$ & 4.1 & 0.20 & $2.8-3.5$ & 3.1 & 0.23 & $0.4-0.8$ & 0.6 & 0.11 \\
\hline 6 & 9 & $5.4-6.1$ & 5.6 & 0.22 & $8.1-8-9$ & 8.4 & 0.29 & $4.5-5.0$ & 4.7 & 0.10 & $4.2-4.9$ & 4.6 & 0.22 & $3.1-3.7$ & 3.3 & 0.19 & $0.5-0.9$ & 0.7 & 0.12 \\
\hline $7 \mathrm{a}$ & 5 & $5.2-5.6$ & 5.4 & 0.19 & $6.0-7.0$ & 6.4 & 0.40 & $3.4-4.2$ & 3.7 & 0.30 & $3.2-3.8$ & 3.4 & 0.23 & $2.7-3.1$ & 2.9 & 0.19 & $0.4-0.7$ & 0.5 & 0.12 \\
\hline $7 \mathrm{~b}$ & 9 & $5.2-5.7$ & 5.5 & 0.17 & $6.3-9.5$ & 7.6 & 1.23 & $3.8-5.2$ & 4.4 & 0.58 & $3.4-5.1$ & 4.1 & 0.67 & $2.7-3.7$ & 3.2 & 0.40 & $0.5-0.8$ & 0.7 & 0.11 \\
\hline $8 a$ & 16 & $5.2-5.9$ & 5.5 & 0.18 & $5.7-6.8$ & 6.3 & 0.27 & $3.1-3.8$ & 3.5 & 0.19 & $3.1-3.9$ & 3.5 & 0.18 & $2.3-3.0$ & 2.8 & 0.16 & $0.4-0.7$ & 0.5 & 0.08 \\
\hline $8 b$ & 9 & $5.2-5.8$ & 5.6 & 0.26 & $6.3-7.8$ & 7.3 & 0.56 & $3.3-4.5$ & 4.0 & 0.39 & $3.3-4.1$ & 3.8 & 0.31 & $2.7-3.2$ & 3.0 & 0.17 & $0.4-0.7$ & 0.6 & 0.11 \\
\hline 9 & 23 & $5.5-6.0$ & 5.7 & 0.12 & $7.4-8.5$ & 8.1 & 0.29 & $4.2-5.1$ & 4.7 & 0.28 & $3.9-4.6$ & 4.3 & 0.20 & $2.9-3.5$ & 3.2 & 0.14 & $0.5-1.0$ & 0.8 & 0.15 \\
\hline 10 & 8 & $4.7-6.2$ & 5.7 & 0.48 & $6.8-10.2$ & 8.7 & 1.03 & $3.8-5.7$ & 5.0 & 0.62 & $3.9-5.2$ & 4.8 & 0.43 & $2.8-3.9$ & 3.4 & 0.36 & $0.6-1.0$ & 0.8 & 0.13 \\
\hline 11 & 11 & $5.6-6.7$ & 5.9 & 0.30 & $7.5-8.7$ & 8.1 & 0.35 & $4.2-5.2$ & 4.7 & 0.33 & $4.1-4.7$ & 4.4 & 0.18 & $2.8-3.4$ & 3.2 & 0.17 & $0.6-1.0$ & 0.8 & 0.15 \\
\hline 12 & 16 & $5.7-6.3$ & 5.9 & 0.18 & $7.0-8.0$ & 7.5 & 0.25 & $4.0-4.7$ & 4.3 & 0.23 & $3.8-4.4$ & 4.1 & 0.22 & $2.7-3.2$ & 2.9 & 0.16 & $0.5-0.9$ & 0.7 & 0.11 \\
\hline $13 a$ & 16 & $5.2-5.7$ & 5.5 & 0.14 & $5.4-7.2$ & 6.5 & 0.43 & $3.2-4.2$ & 3.6 & 0.27 & $3.0-4.0$ & 3.5 & 0.26 & $2.4-3.0$ & 2.8 & 0.18 & $0.3-0.8$ & 0.5 & 0.13 \\
\hline $13 b$ & 16 & $5.5-6.3$ & 5.9 & 0.21 & $7.2-9.3$ & 8.2 & 0.49 & $4.1-5.4$ & 4.7 & 0.33 & $3.8-5.0$ & 4.4 & 0.28 & $3.1-3.7$ & 3.4 & 0.18 & $0.5-1.0$ & 0.7 & 0.14 \\
\hline $14 a$ & 17 & $5.4-6.3$ & 5.8 & 0.24 & $5.7-8.4$ & 7.3 & 0.88 & $3.0-4.8$ & 4.0 & 0.53 & $3.2-4.6$ & 3.9 & 0.45 & $2.3-3.2$ & 2.9 & 0.26 & $0.4-1.0$ & 0.7 & 0.19 \\
\hline $14 b$ & 17 & $5.6-6.1$ & 5.8 & 0.12 & $7.5-9.2$ & 8.2 & 0.47 & $4.2-4.8$ & 4.5 & 0.25 & $3.7-4.8$ & 4.4 & 0.25 & $2.9-3.7$ & 3.3 & 0.21 & $0.5-0.9$ & 0.7 & 0.13 \\
\hline 15 & 16 & $5.2-5.8$ & 5.5 & 0.22 & $6.5-9.1$ & 7.8 & 0.82 & $3.8-5.2$ & 4.5 & 0.42 & $3.6-4.8$ & 4.3 & 0.40 & $3.0-3.7$ & 3.3 & 0.22 & $0.4-1.0$ & 0.7 & 0.16 \\
\hline 16 & 11 & $4.5-5.8$ & 5.5 & 0.37 & $6.4-8.7$ & 7.6 & 0.65 & $3.5-5.1$ & 4.3 & 0.45 & $3.7-4.8$ & 4.1 & 0.32 & $2.6-3.6$ & 3.2 & 0.28 & $0.5-0.8$ & 0.7 & 0.11 \\
\hline 17 & 18 & $5.5-6.2$ & 5.8 & 0.22 & $8.0-9.4$ & 8.6 & 0.43 & $4.5-5.8$ & 5.0 & 0.32 & $4.2-5.0$ & 4.6 & 0.21 & $3.3-3.9$ & 3.5 & 0.15 & $0.6-1.0$ & 0.8 & 0.12 \\
\hline \multicolumn{20}{|c|}{ Flores } \\
\hline 19 & 21 & $5.0-6.3$ & 5.7 & 0.35 & $4.9-11.6$ & 9.0 & 2.22 & $2.6-6.2$ & 4.6 & 1.12 & $2.7-6.5$ & 5.0 & 1.18 & $1.9-4.1$ & 3.3 & 0.74 & $0.3-0.9$ & 0.6 & 0.18 \\
\hline 20 & 20 & $4.7-7.1$ & 6.3 & 0.61 & $5.9-8.3$ & 7.4 & 0.61 & $3.0-4.5$ & 3.8 & 0.35 & $3.0-4.3$ & 3.9 & 0.33 & $2.2-2.8$ & 2.6 & 0.18 & $0.3-1.0$ & 0.7 & 0.17 \\
\hline 21 & 13 & $5.2-5.8$ & 5.5 & 0.18 & $7.8-10.1$ & 9.3 & 0.76 & $4.1-5.3$ & 4.7 & 0.37 & $4.2-5.4$ & 4.9 & 0.38 & $3.0-3.8$ & 3.4 & 0.29 & $0.5-0.8$ & 0.7 & 0.11 \\
\hline 22 & 29 & $4.9-5.9$ & 5.4 & 0.26 & $5.8-10.0$ & 7.7 & 1.23 & $2.7-5.3$ & 3.9 & 0.76 & $3.0-5.3$ & 4.1 & 0.64 & $2.1-3.5$ & 2.8 & 0.48 & $0.3-0.8$ & 0.5 & 0.14 \\
\hline
\end{tabular}


oldest rocks are more than 2.5 Mys old and in the island's formation two main complexes can be recognized: the base complex which ended about 0.7 Mys ago, and the upper complex, of which the last eruptive events were date of about 3,000 years ago (Azevedo et al., 1986). Together with tiny Corvo $\left(17 \mathrm{~km}^{2}\right)$, they are the most remote islands of the archipelago.

\section{Drouetia Gude, 1911}

Helix atlantica Morelet and Drouët, 1857 was characterized by the absence of umbilical perforation. It was on account of that character that Gude (1911) created the genus Drouetia for that species, Riedel (1964), following Zilch's (1959) tentative proposal, lowered Gude's taxon to the subgeneric level.

In the original description there was no mention to the geographic range of that species nor of its type locality, but Morelet (1860) considered $H$. atlantica as spread throughout most of the islands, being most common in S. Miguel. Acknowledging its variability in shell morphology, he assigned varieties to the populations of Faial and Santa Maria. Riedel (1964), based upon anatomical studies, raised to subspecific rank Morelet's variety H. a. minor, from Faial, as well as the large specimens from Santa Maria, which he named

Table 3 Discriminant scores from functions 1 (A) and 2 (B) of canonical analysis of shell morphometry of the populations from São Miguel (stations 5-17). Tukey HSD. Means for groups in homogeneous subsets are displayed. Based on Type III Sum of Squares. The error term is Mean Square.(Error) $=1,000$.

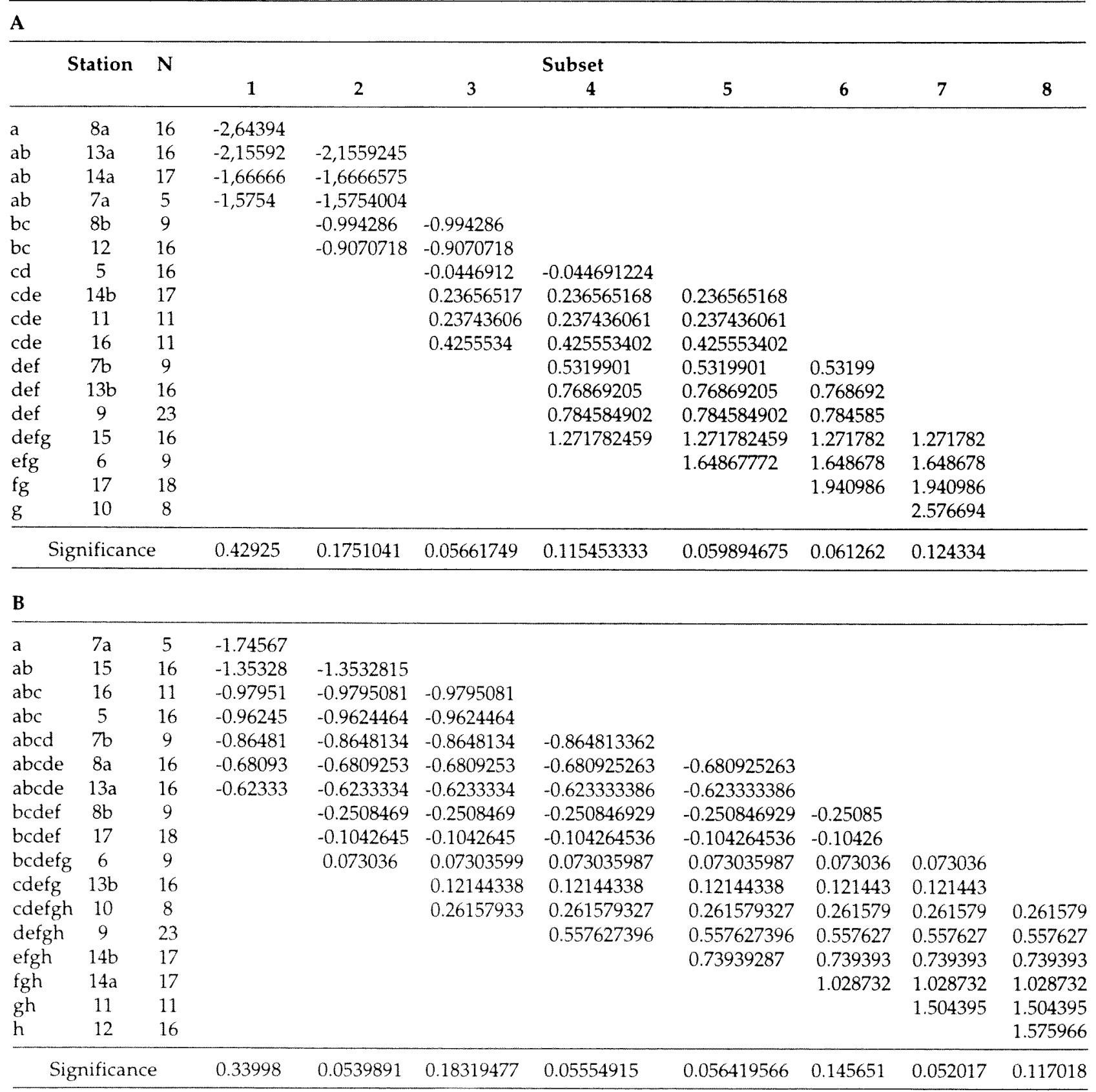


Oxychilus (Drouetia) atlanticus brincki; he also raised to specific status Morelet's variety H. a. spectabilis, from Santa Maria, for which he created the subgenus Atlantoxychilus. Martins (1981) described $O$. (D.) agostinhoi from Santa Maria, thus rendering Drouetia a polytypic taxon; later (1989) he described two new species from Terceira, $(O$. (D.) miceui and O. (D.) furtadoi). In that same year Winter described $O$. (D.) batalhana from São Miguel. Martins et al. (1991) and Cunha et al. (1993) raised to the specific category Riedel's subspecies from Santa Maria and Faial, respectively.

\section{Taxonomic list of the Oxychilus Fitzinger} mentioned in the text:

Drouetia Gude, 1911

Oxychilus (Drouetia) atlanticus (Morelet and

Drouët, 1857)

[= O. (D.) batalhana Winter, 1989]

O. (D.) minor (Morelet, 1860)

O. (D.) brincki Riedel, 1964

O. (D.) agostinhoi Martins, 1981

O. (D.) miceui Martins, 1989

O. (D.) furtadoi Martins, 1989

Atlantoxychilus Riedel, 1964

Oxychilus (Atlantoxychilus) spectabilis (Morelet, 1860)

\section{RESULTS}

Analysis of shell morphometry of the specimens from São Miguel showed that, although some stations were significantly different from each other, there was great overlap in shell shape around the island and the similarities did not reveal any definable geographic pattern (Table 2; Figure 3). Replicates of some stations did show significant differences (Table 3). Cluster analysis was performed and confirmed the lack of pattern shown by canonical analysis.

Wide range of sizes was found in the samples of stations $7 \mathrm{~b}$ and 10 (shell diameter SD 1.23 and 1.03, respectively), revealing stronger heterogeneity.

Inspection of the anatomy of the reproductive system, on the other hand, showed good constancy in morphology within station, but varied somewhat haphazardly between stations (Figure 4). No remarkable differences were detected among the replicates of stations. The length of the epiphallus and of the penial sheath were the characters that showed more disparate differences (see Figure 2 for terminology). Worth mention is the rugose aspect of the epiphallic pore in specimens of station 7 (Figure 4,7 ) and to a lesser extent represented also in specimens from station 8 (Figures 4,$8 ; 10, \mathrm{~A}$ ).

The specimens from Flores revealed a different

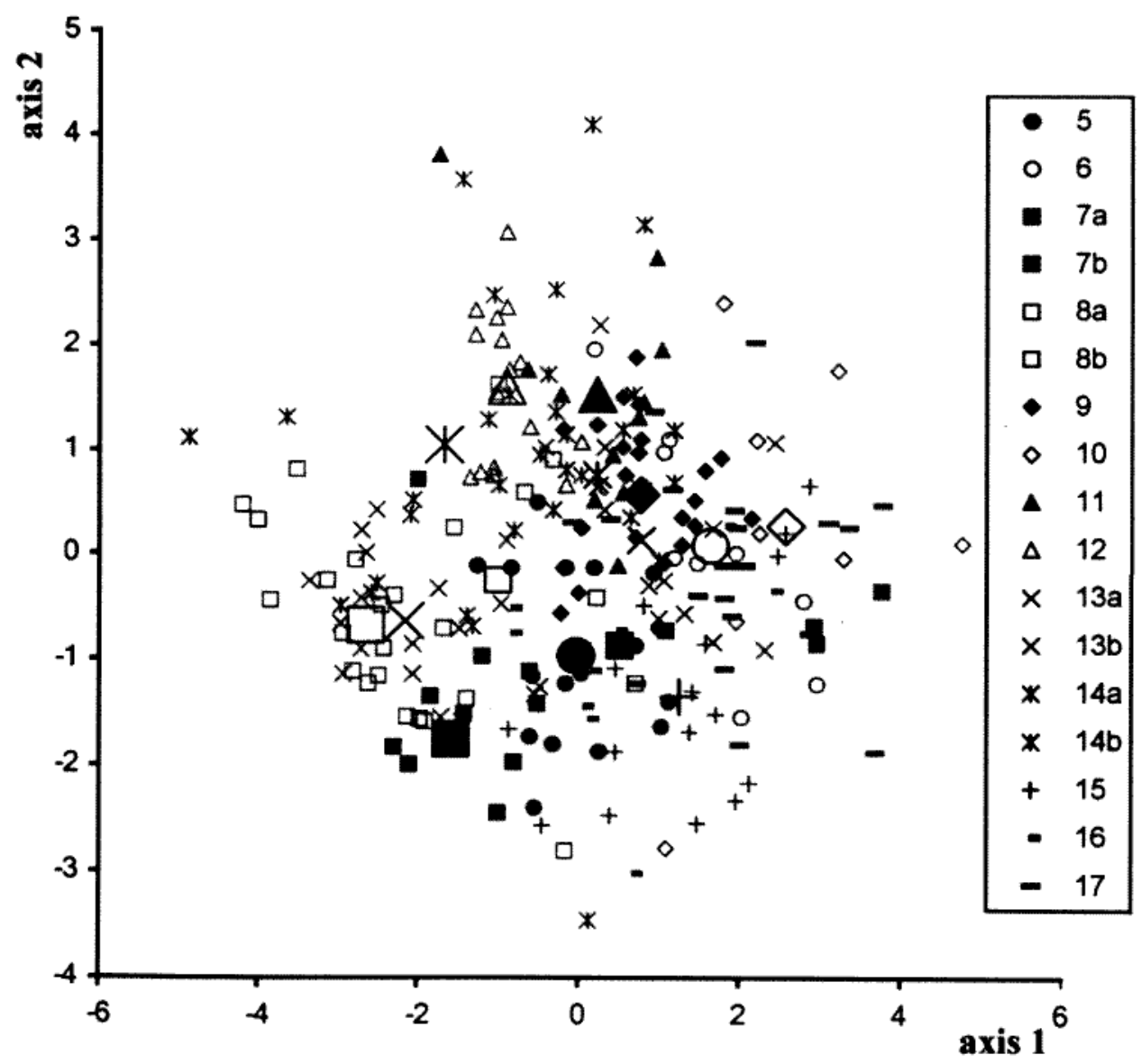

Figure 3 Projection of the specimens from São Miguel (stations 5-17, Table 1), according to the first two canonical functions extracted from shell morphometry (Table 2). The larger symbols represent the centroids for each station. Where there was duplicate sampling $(a, b), b$ is represented by the smaller centroid. 
Table 4 Discriminant scores from functions 1 (A) and 2 (B) of canonical analysis of shell morphometry of the populations from Flores (stations 19-22). Tukey HSD. Means for groups in homogeneous subsets are displayed. Based on Type III Sum of Squares. The error term is Mean Square (Error) $=1.000$.

A

\begin{tabular}{lccccc}
\hline & Station & $\mathbf{N}$ & $\mathbf{1}$ & $\begin{array}{c}\text { Subset } \\
\mathbf{2}\end{array}$ & $\mathbf{3}$ \\
\hline $\mathrm{a}$ & 21 & 13 & -1.469514986 & & \\
$\mathrm{ab}$ & 19 & 21 & -0.657685886 & -0.6576859 & \\
$\mathrm{~b}$ & 22 & 29 & & -0.5377883 & 2.425548 \\
$\mathrm{c}$ & 20 & 20 & & & 1 \\
\hline \multicolumn{7}{c}{} & & 0.065873562 & 0.9824623 & \\
\hline B & Significance & & & \\
\hline $\mathrm{a}$ & 21 & 13 & -0.594310859 & & \\
$\mathrm{a}$ & 22 & 29 & -0.320505071 & & \\
$\mathrm{a}$ & 20 & 20 & -0.083643016 & 0.890169 & \\
$\mathrm{~b}$ & 19 & 21 & & 1 & \\
\hline
\end{tabular}

pattern. Basic statistical analysis showed heterogeneity in samples from stations 19 and 22 (SD of shell diameter was 2.22 and 1.23 , respectively; Table 2), and canonical analysis of shell morphology showed that station 20 was set apart from the others, thus indicating that it could harbour a different populational unit (Table 4; Figure 5). Cluster analysis revealed that various such units could be identified, and that they are largely syntopic (Figure 6). Inspection of the shell morphology of the specimens thus grouped suggested that four relatively homogeneous units could be made.

The anatomy of those tentatively identified units, however, apart from relative size, deviates little from a basic design. The most obvious, perhaps unique feature shared by all groups from Flores, but absent in Drouetia from the other islands, is the smooth interior of the proximal penis (Figures $7 ; 10, \mathrm{E}-\mathrm{H}$ ).

Still a different pattern was found in Graciosa. Syntopic specimens, impossible to set apart on the basis of shell morphology alone, are strikingly different in almost every aspect of their reproductive anatomies (Figures $8 ; 10, \mathrm{C}-\mathrm{D}$ ).

Santa Maria has four anatomically wellestablished species. Oxychilus (D.) agostinhoi is the smallest Drouetia of the archipelago (Figure 9, A). Oxychilus (D.) brincki and O. (Drouetia) sp. G, somewhat similar conchologically, are very distinct anatomically (Figure 9, B-C). Oxychilus (Atlantoxychilus) spectabilis, apart from the peculiar groove on the whorls, has a typical Drouetia-like shell; however, the internal morphology of the penis is remarkably different (Figures 9, D; 10, L).

\section{DISCUSSION}

\section{The patterns}

The zonitids are the most speciose pulmonate group in the Azores and are responsible for about one third of its endemic species (Riedel, 1997; Martins, 1999). Such species diversity is expressed not only in the morphology of the shell or, mainly, anatomically but also in the coloration of the animal. Whereas most European zonitids are uniformly dark-blue, the Azorian endemics may exhibit vivid coloration not only on the exposed parts of the body (foot sole and sides) but also on the mantle, visible through the translucent shell Coloration of the foot may sometimes be related with food sources; some brightly coloured animals were seen feeding on the red wrapping of the seeds of Accacia or on the succulent red fruits of Hedychium, although that same coloration has been found when such food sources were not available. Therefore, the presence of various foot colorations in a population should not warrant, per se, a taxonomic status, unless consistently linked to other diagnostic characters.

Shell morphology in São Miguel did not show any identifiable pattern of variability, although significant differences were found among some stations (Table 3; Figure 3). However, significant differences were also found between duplicates of the same station (collected months or years apart), thus indicating that variability in shell morphology, besides having some inter-demic expression, could also have associated an intra-demic cohort factor. 


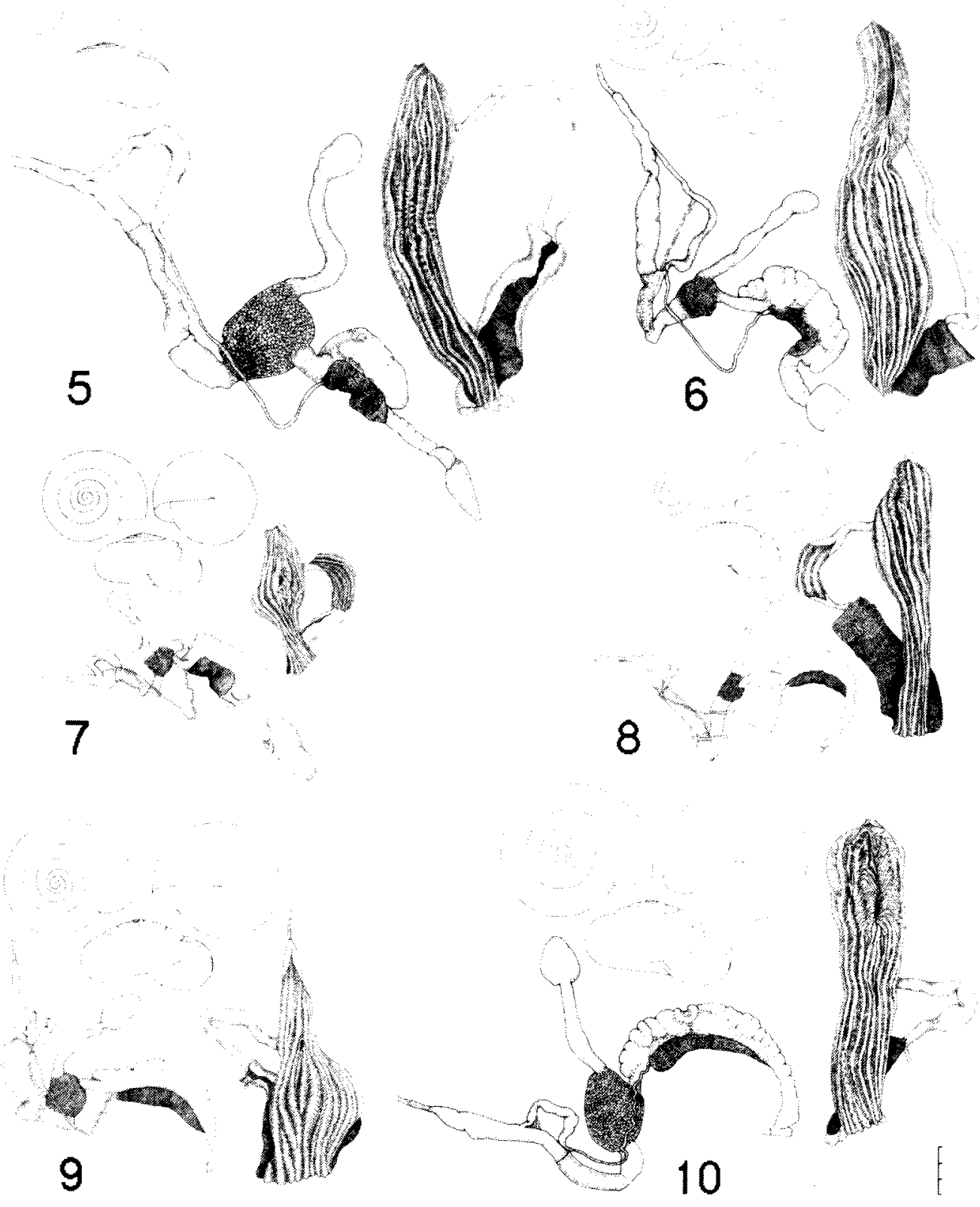

Figure 4 Oxychilus (Drouetia) atlanticus, from São Miguel. Pictorial representation of the shell, genitalia and internal morphology of the penis of a specimen from each station (5-17). Scale bar $=1 \mathrm{~mm}$ (one division for the shell; two divisions for the genitalia; full length for the penis).

The disparate sizes found in stations $7 \mathrm{~b}$ and 10 (see also Martins, 1991, figures 4-5) could be related to cohort overlapping; Cunha (1999) has found that $O$. (D.) atlanticus lives to 24-26 months and matures at about 14 months. It appears, then, that on account of shell morphology only one species $(O$. (D.) atlanticus) exists in the island.

Anatomy, on the other hand, maintained a more obvious demic nature, even taking into account that Martins (1991) had cautioned against the variability expressed in the relative dimensions of the reproductive system, often an artifact of different preservation methods. This is clearly the case of $O$.
(D.) batalhana (see Figures 4,12), described on the basis of the relative proportions of highly variable structures such as the flagellum, but which, for other reasons as well, fits well within the observed variability in São Miguel. Oxychilus (D.) batalhana shall, then, be considered a junior synonym of $O$. (D.) atlanticus. Anatomical variability throughout the island does not follow a consistent pattern of relationships: demes closer are sometimes more different than are demes further apart (compare, e.g., in Figure 4, stations 9-10, located side by side or 6-17, at opposite ends of the island). The demic (allotopic) nature of the observed variability 


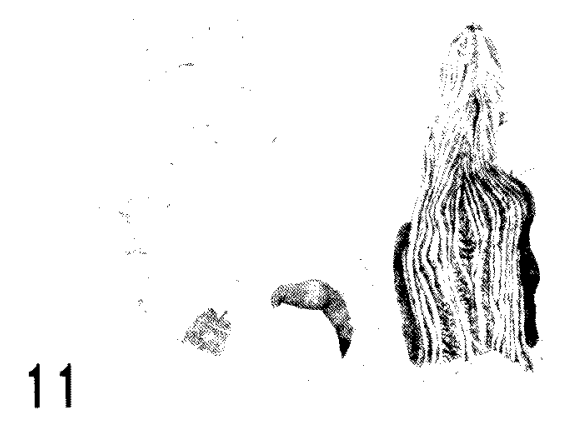

14
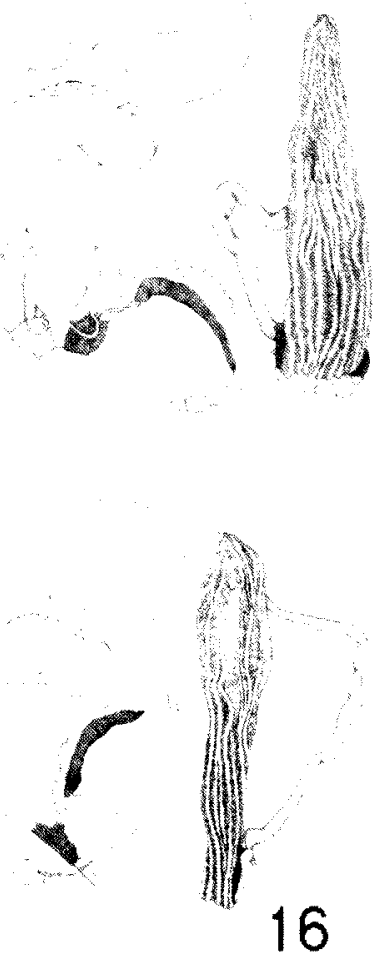

Figure 4 (cont.)

corroborates the findings based on shell morphology that only one species lives in the island.

The situation in Flores, however, is rather different. The anatomical characters, although in some peculiarities (internal ornamentation of the proximal penis) not comparable to those from other islands, exhibit there a rather clear homogeneity. Shell shape, on the other hand, clearly sorts the specimens from the various stations (Table 4; Figure 6). Contrary to the situation in Saao Miguel, it appears that in Flores various taxonomic units exist, for the various groups occur syntopically.
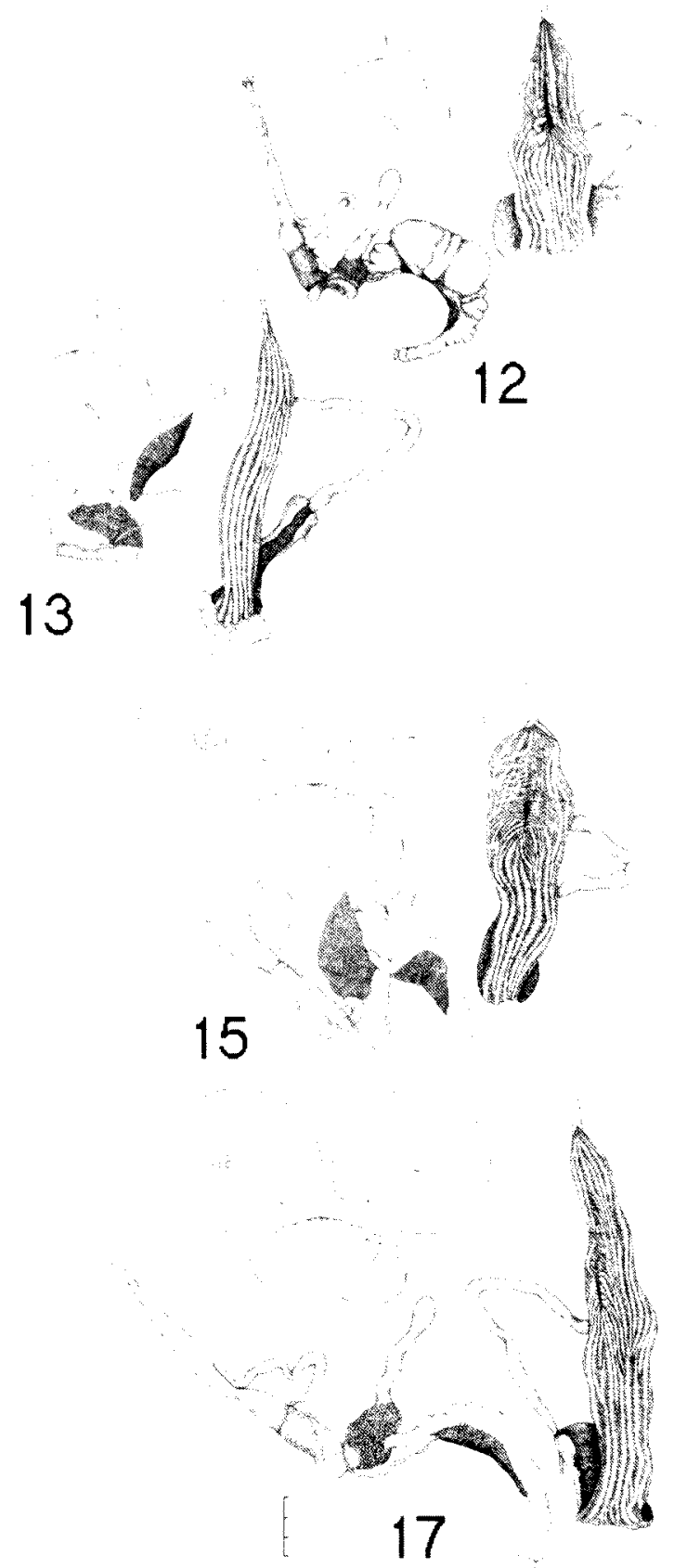

I previously stated that body coloration, per se, is not a reliable character; however, inspection of the coloration of the foot appears to be helpful in this case. Within some variational latitude, sp. A has a yellowish foot, sp. B is whitish, sp. C is black and sp. $\mathrm{D}$ is pink. The markings on the mantle are clearly seen in species $C$ and $D$, less so in the other two. It appears, then, that coloration corroborates shell variability, in spite of some anatomical uniformity.

In Graciosa still another pattern emerges. The shells of syntopic specimens are indistinguishable but the morphology of the reproductive system is 


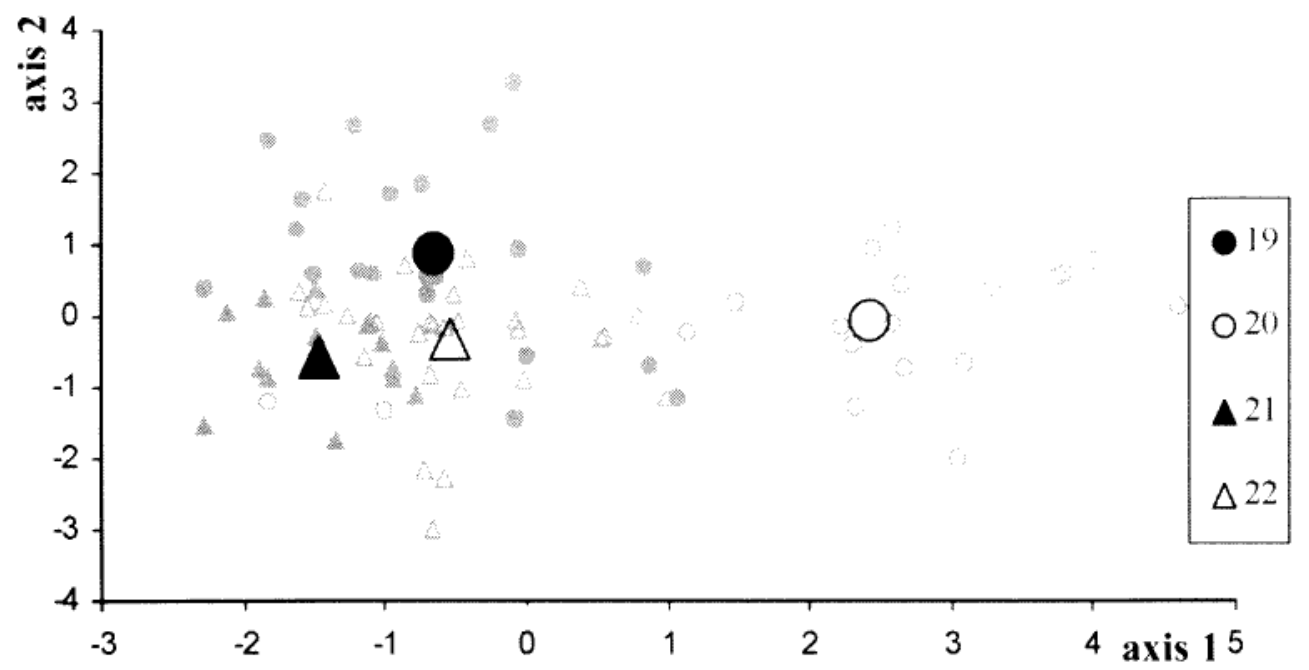

Figure 5 Projection of the specimens from Flores (stations 19-22; Table 1), according to the first two canonical functions extracted from shell morphometry (Table 2). The larger symbols represent the centroids for each station.

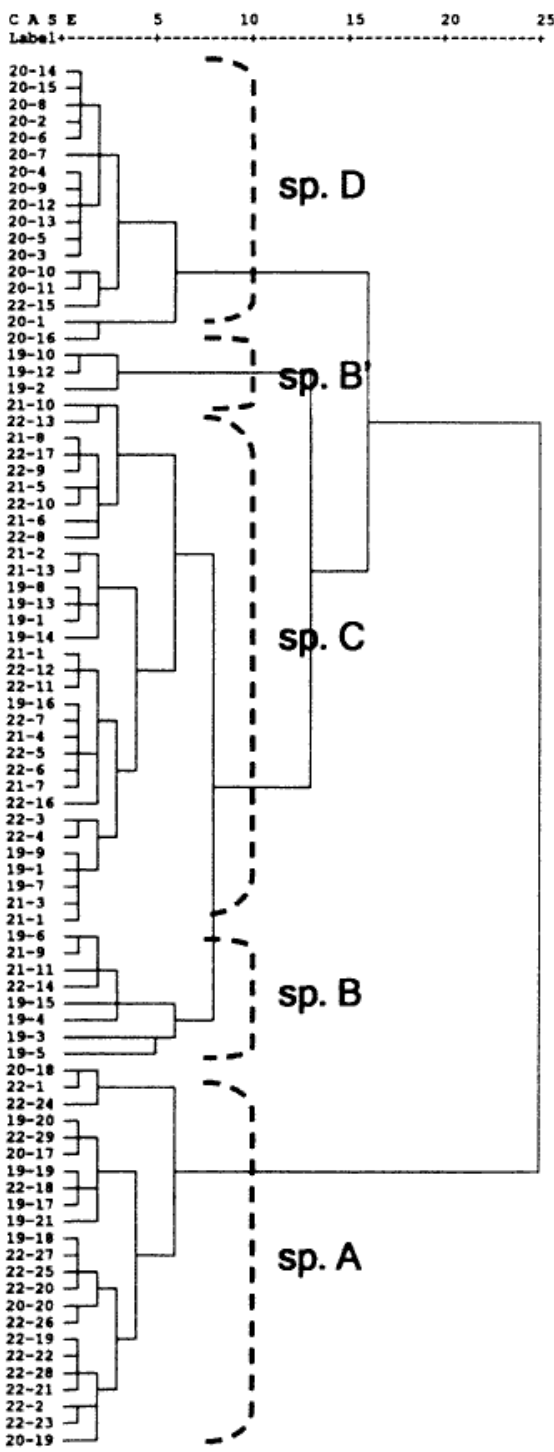

Figure 6 Dendrogram of specimens from Flores (stations 19-22), resulting from cluster analysis (euclidean distance followed by UPGMA) based on shell morphology (Table 2). Several units (sp. A-D) stand out as having possible taxonomic significance.

drastically different (Figure 8, spp. E-F): the relative proportions of the penial sheath, the shape of the epiphallus, the length of the vagina. Inspection of the animals does not yield clearer diagnostic results than the shells: the animals are of a tender pink, much like those of $O$. (D.) minor from Faial and somewhat similar to sp. A from Flores. However, the fact that they live syntopically and that they consistently exhibit such disparate, complex anatomies, without intermediates, is clear indication of the presence of two discrete taxonomic units.

The groups in Santa Maria are markedly separate. Oxychilus (D.) agostinhoi, the smallest Drouetia of the archipelago, apart from its minute size and flat spire, shows more anatomical similarities with the species of the remaining islands than any of the other species from Santa Maria (Figures 9; 10; see also Martins, 1981). Oxychilus (D.) brincki and O. (Drouetia) sp. G are somewhat similar conchologically and have been confused since Morelet and Drouët's (1857) description, for both shells appear in the type material (personal observation). However, their anatomies are very distinct and unlike any other species in the Azores (Figures 9, B-C; 10, J, K). Oxychilus (Atlantoxychilus) spectabilis, apart from the characteristic furrow around the equator of the last whorl and spiralling up on the spire, has a typical Drouetia-like shell; however, the internal morphology of the penis is so remarkably different that is was placed by Riedel (1964) into a separate subgenus (Figures 9, D; 10, L).

The species from Santa Maria exhibit also discrete colour variations. Oxychilus (D.) agostinhoi somewhat resembles the European zonitids being dark blue on top and clearing toward the foot, which has a dark rim around it; the mantle markings can hardly be seen through the greenish shell. Oxychilus (D.) brincki has bright orange foot and mantle markings similar to some specimens 


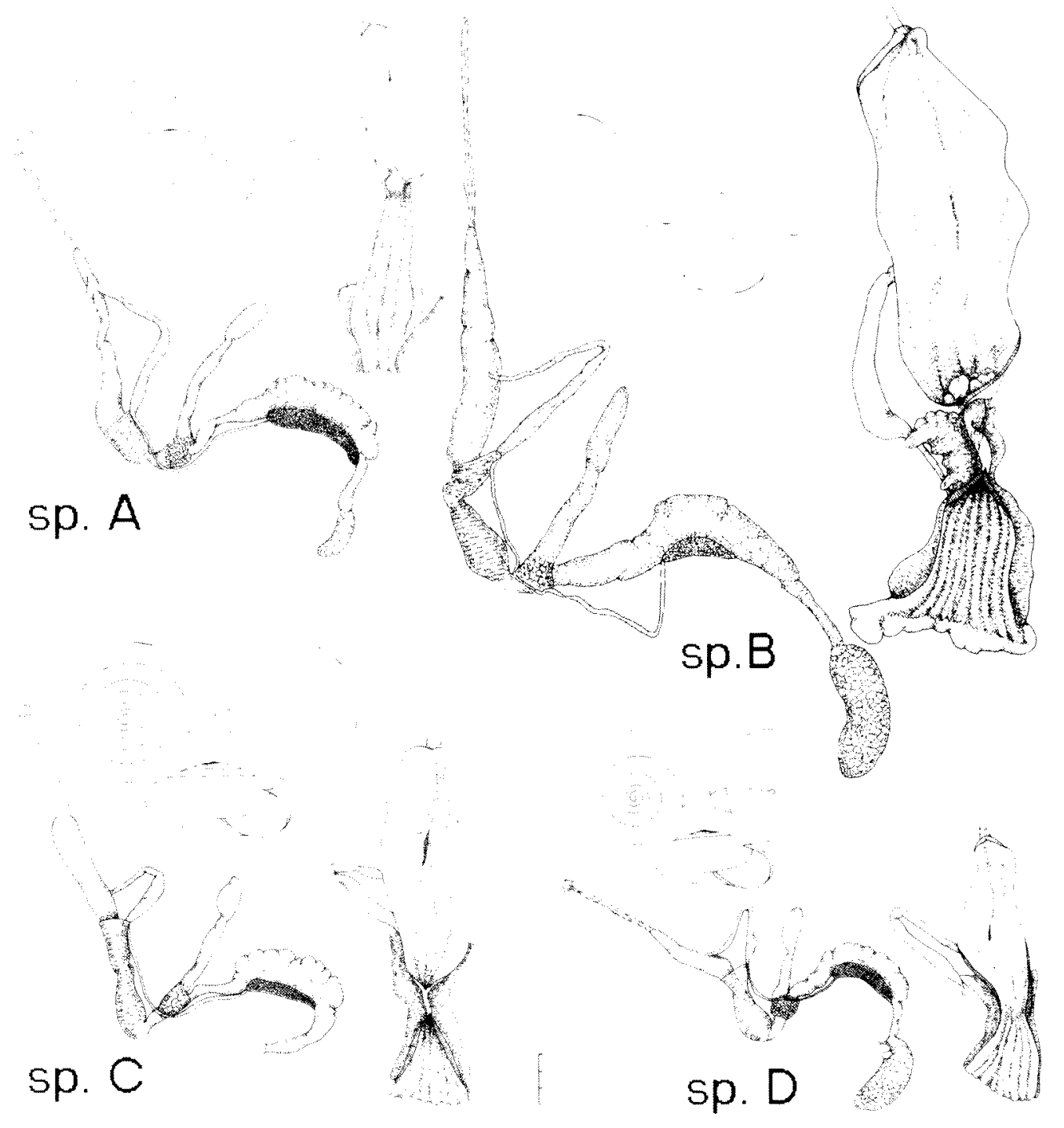

Figure 7 Oxychilus (Drouetia) sp. from Flores. Pictorial representation of the shell, genitalia and internal morphology of the penis of a specimen from each (taxonomic) unit (A-D), as expressed in Figure 6. Scale bar $=1 \mathrm{~mm}$ (one division for the shell; two divisions for the genitalia; full length for the penis).

from São Miguel. Oxychilus (D.) sp. G is greenish with yellowish mantle markings and $O$. (A.) spectabilis is dark yellow with clear mantle markings.

\section{The process}

Speciation is usually a time requiring phenomenon that can rarely be followed in its entirety. Apart from direct reading of the fossil record, the process of speciation can be inferred through a comparative and integrative approach

Several stages of speciation were presented above and various patterns of differentiation exposed. Integrating the various situations may help understanding some elements influencing the process.

Various scenarios are proposed:

a) demic (allotopic) variability in São Miguel. Assuming that $O$. (D.) atlanticus constitutes one (variable) population on the entire island, the observed differences could perhaps be explained if one admits a strong demic structure in that population, reinforced by gregarious behaviour. Such structure would require an endogenous mechanism of short-term variability (associated with pioneering, i.e., frequent colonization and/or population reduction, and strongly influenced by genetic drift) in order to explain the significant differences observed in the duplicate sampling in some stations. Cunha (1999) observed that $O$. (D.) atlanticus congregate under logs or rocks to lay eggs, a behaviour that may contribute to some dampening of inter-demic gene flow. However, natural expansion of the demes is unavoidable and eventually gene flow is re-established, thus requiring recurrent fragmentation of these larger demes to explain the observed pattern. Cyclic volcanic eruptions could well be an essential part of such fragmenting mechanism, and the volcanological history of São Miguel, presented 


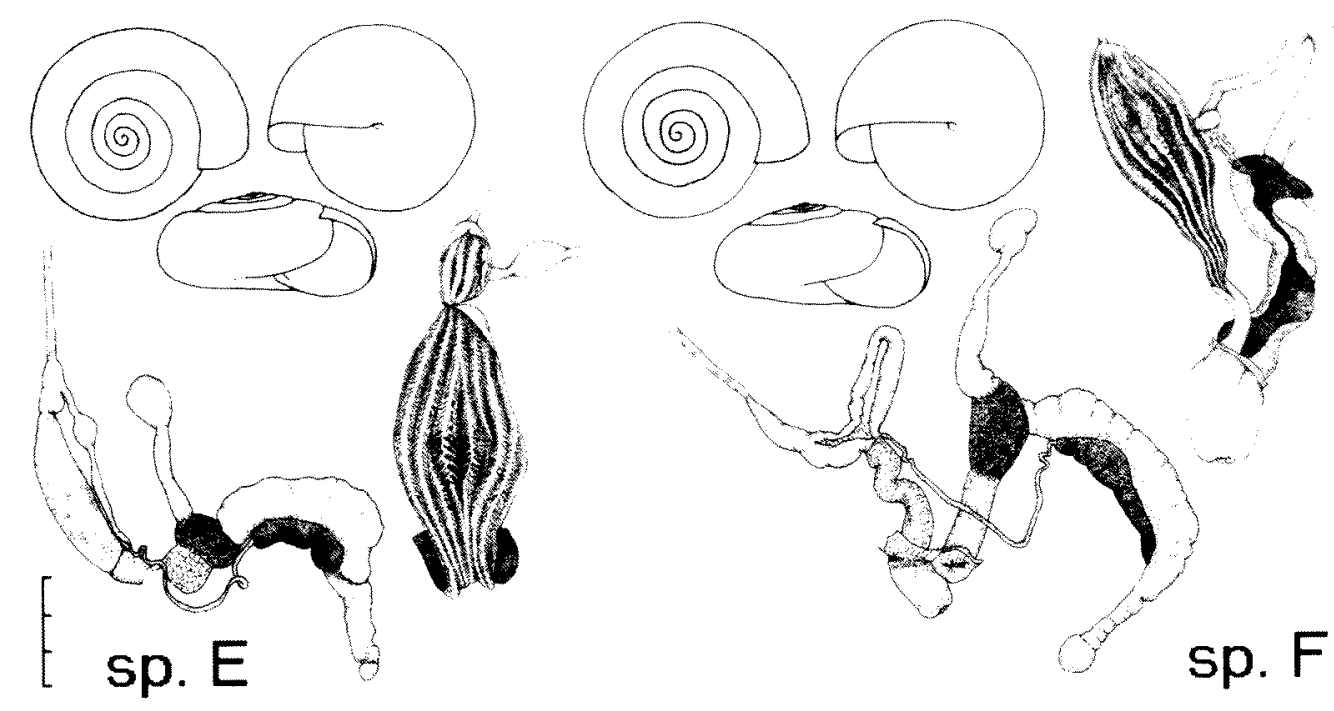

Figure 8 Oxychilus (Droutetia) sp. from Graciosa. Pictorial representation of the shell, genitalia and internal morphology of the penis of a specimen from each (taxonomic) unit (sp. E and sp. F). Scale bar $=1 \mathrm{~mm}$ (one division for the shell; two divisions for the genitalia; full length for the penis).

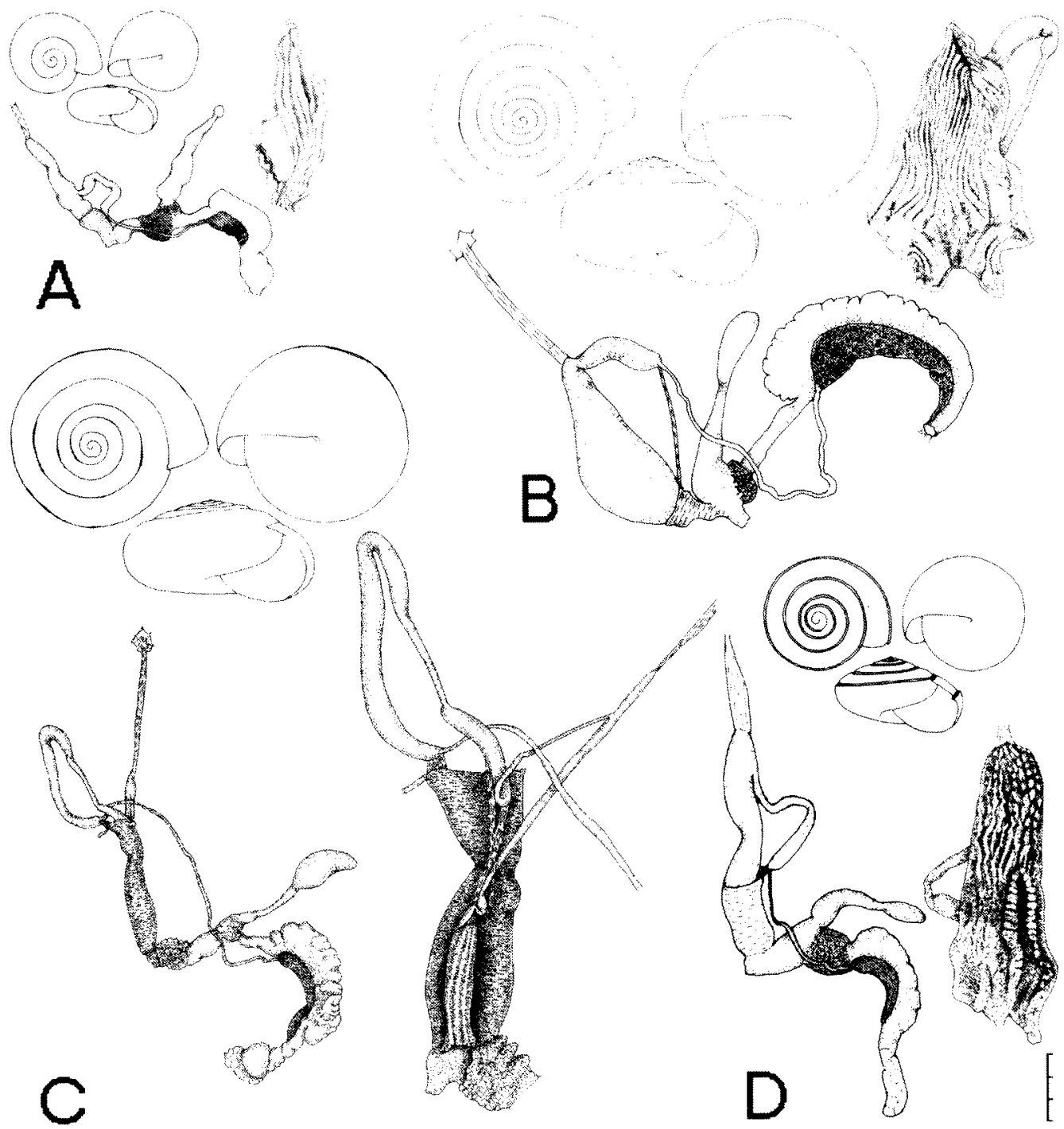

Figure 9 Oxychilus from Santa Maria. Pictorial representation of the shell, genitalia and internal morphology of the penis. A, Oxychilus (Drouetia) agostinhoi; B, Oxychilus (Drouetia) brincki; C, Oxychilus (Drouetia) sp. G; D, Oxychilus (Atlantoxychilus) spectabilis. Scale bar $=1 \mathrm{~mm}$ (one division for the shell; two divisions for the genitalia; full length for the penis). 


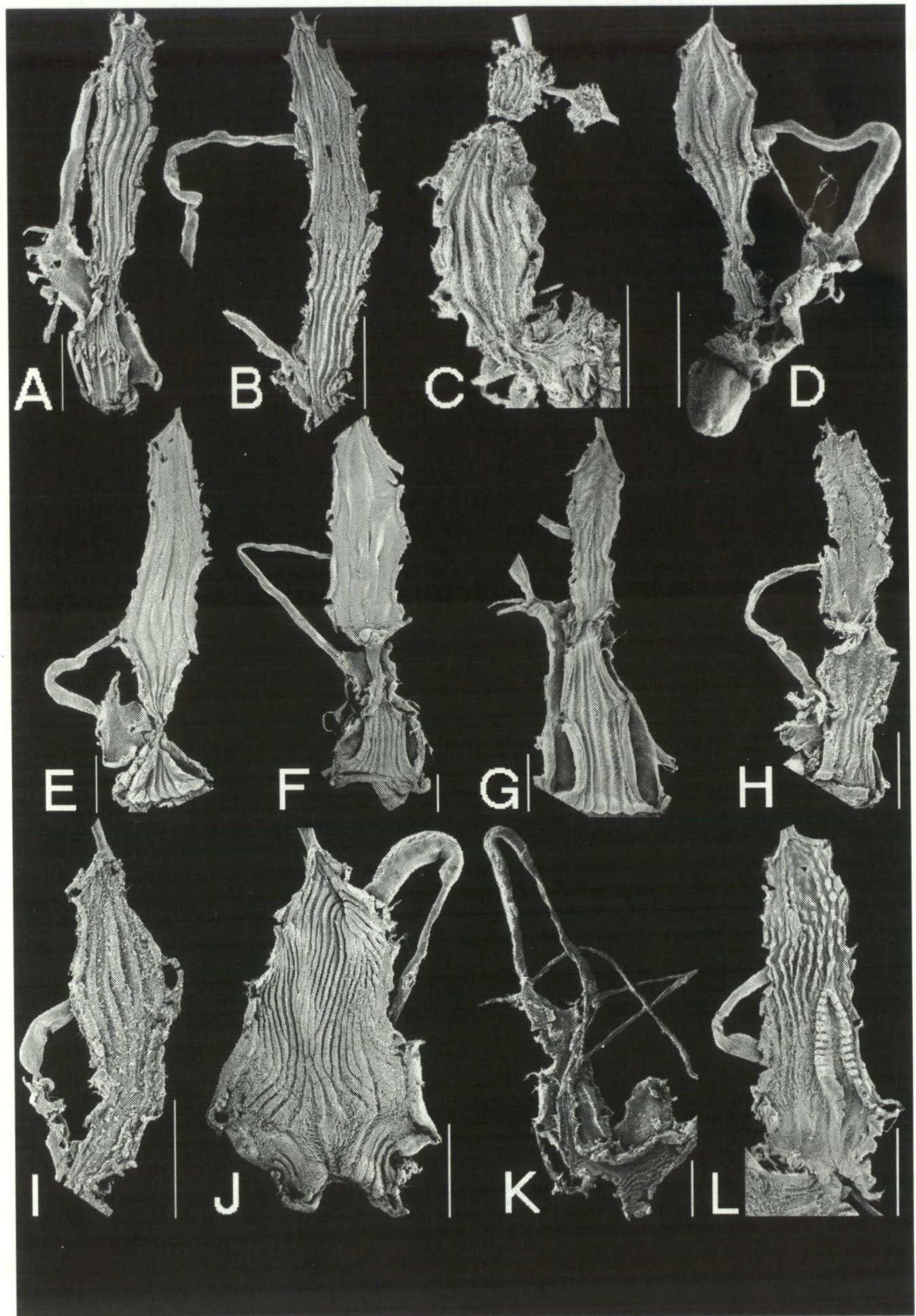

Figure 10 Internal morphology (SEM) of the penis of various species of Oxychilus. A-B, O. (Drouetia) atlanticus (S. Miguel, Sta 8 and Sta 16); C-D, Oxychilus (D.) sp. E and sp. F (Graciosa, Sta 18); E-H, Oxychilus (D.) sp. A (Sta 20), sp. B (Sta 19), sp. C (Lagoa Seca, 18-10-1993) and sp. D (Sta. 19) (Flores); I-L (Santa Maria): I, O. (D.) agostinhoi (Sta 1, 1993); J, O. (D.) brincki (Sta 1, 1974); K, Oxychilus sp. G (Sta 3); L, O. (Atlantoxychilus) spectabilis (Sta 4). Scale bars $=1 \mathrm{~mm}$.

above, meets these requirements. Van Riel et al. (2003) have linked genetic differentiation of the endemic Leptaxis azorica (Albers) with the geological age of São Miguel. Their study concluded that eastern and western populations differ significantly and that those in the middle are intermediate.
Although the present study progressed as a different approach for it is circumscribed to morphology and anatomy, it takes some legitimacy in Van Riel's findings. How quickly does the biota recover after profound eruptive disturbance can be inferred from Sta 13, Pico do Fogo, which erupted 
in 1652; the area is now a rich haven for endemic molluscs. One could, then, assume that within a 200 years span the effects of the eruption had already disappeared and that the colonizers who founded the Pico do Fogo deme would sporadically connect with those nearby. Some eruptions were much stronger than the one just mentioned and affected greater area of the island. Walker and Croasdale (1971) and Booth et al. (1978) quantified the deposits of two major eruptions of the Água de Pau volcano (Fogo complex, Figure 1, e), in 4600 B.C. and 1563 A.D. The first one practically cut the island in half and the deposits of the second one reached half a meter as far as Nordeste, at the eastern tip of the island. Curiously, this study corroborated the vivid historical narrative of Gaspar Frutuoso (1522-1591), the first historian of the islands, who reported at length the destruction caused by the eruption. An additional fragmenting mechanism could be the strong erosion that newly formed land is submitted to, with the formation of deeply cut ravines.

Hypothetical as it may seem, the aforementioned mechanism assumes relevance as explanatory when we realize that part of São Miguel is 4 Mys old and Drouetia may have reached the (proto)island long enough to have speciated, as it did elsewhere in the archipelago. However, unless a syntopic situation arises where distinct morphologies/anatomies are clearly diagnosed, multiple species will not be detected by the present approach, in spite of the wide range of morphological and anatomical variability herein registered. If such fragmentation mechanism (or another plausible one) is not taken into account, this one species of Drouetia living there now had to be a newcomer, thus requiring catastrophic extinction of previous colonizers and a re-colonization event, of unclear origin.

b) close interspecific (syntopic) variability in Flores and in Graciosa. In both cases volcanic activity (perturbation) has been absent for at least 2,000 years. Other mechanisms may have created allopatry and allowed for speciation to progress to the point where, when syntopic, we can say they behave as discrete evolutionary units, perhaps as biological species. The close anatomical resemblance of the specimens from Flores, although conchologically and externally separable, and the conchological and external resemblance of the specimens from Graciosa, although anatomically distinct, illustrate the various ways in which speciation can proceed.

c) extreme interspecific (syntopic) variability in Santa Maria. This is a case of progression in time of scenario b), just mentioned. Volcanism has stopped in Santa Maria more than 3 Mys ago. Here time has been the main factor, allowing for the extreme divergence presented above (see Figure 9). The hypothesis of multiple colonization events to explain the present situation in Santa Maria does not fit the reality in the remaining islands nor has it found a suitable source of multiple colonizers. Drouetia has not left relatives in Europe or Macaronesia, the closest source for more than 95\% of the Azorian malacofauna.

\section{AKNOWLEDGEMENTS}

Many colleagues have helped collecting throughout the years the material used in this study (Carlos Brito, Regina Cunha, Armindo Rodrigues, Peter Mordan, Thierry Backeljau); I am grateful to them. Thierry has thoroughly gone through the manuscript and gave me sound, critical advice, which I often took into account; to him and to an anonymous referee goes my gratitude. I also thank Luís Dias e Silva who has skilfully and patiently helped me with the statistical analysis.

This research is part of the on-going project "Evolutionary and colonization patterns of the molluscs of the Azores" - CIRN (Centro para a Investigação dos Recursos Naturais, Universidade dos Açores).

\section{REFERENCES}

Azevedo, J.M.M., Portugal Ferreira, M.R. and Martins, J.A. (1986). O complexo de base da ilha das Flores, Açores. Memórias e Notícias do Laboratório Mineralógico e Geológico da Universidade de Coimbra 101: 56-71.

Booth, B., Croasdale, R. and Walker, G.P.L. (1977). A quantitative study of the five thousand years of volcanism on São Miguel, Azores. Philosophical Transactions of the Royal Society of London. A. Mathematical and Physical Sciences 288(1352): 271-319.

Cunha, R.M.T. (1999). História de vida de Oxychilus (Drouetia) atlanticus (Morelet \& Drouët) (Pulmonata: Zonitidae). Ph.D. dissertation, University of the Azores, Ponta Delgada.

Cunha, R.M.T., Rodrigues, A., Brito, C.P., Winnipenix, B. and Martins, A.M.F. (1993). Moluscos Terrestres da Ilha do Faial. Lista Preliminar. Relatórios e Comunicações do Departamento de Biologia. Expedição Científica Faial/93 22: 53-59.

Feraud, G., Kaneoka, I. and Allègre, C.J. (1980). K/Ar ages and stress pattern in the Azores: geodynamic implications. Earth and Planetary Science Letters 46: 275-286.

Forjaz, V.H.F. (1984). S. Miguel. Volcanostratigraphic Sketch. Departamento de Geociências, Universidade dos Açores.

Frutuoso, G. (1987). Livro Quarto das Saudades da Terra. Instituto Cultural de Ponta Delgada, Ponta Delgada.

Gaspar, J.L. (1996). Ilha Graciosa (Açores). História Vulcanológica e Avaliação do Hazard. Ph.D. Dissertation, University of the Azores, Ponta Delgada.

Gude, G.K (1911). Note on some preoccupied Molluscan generic names and proposed new genera of the family Zonitidae. Proceedings of the Malacological Society of London 9: 269-273. 
Howard, D., and Berlocher, S.H. (editors) (1998). Endless Forms. Oxford University Press, London.

Jenner, R.A. (2004). Accepting partnership by submission? Morphological phylogenetics in a molecular millenium. Systematic Biology 53(2): 333342.

Martins, A.M. de Frias (1981). Oxychilus (Drouetia) agostinhoi new species (Stylommatophora: Zonitidae) from the Azores Islands, its anatomy and phylogenetic relationships. Occasional Papers on Mollusks, The Department of Mollusks, Harvard University 4 (59): 245-264.

Martins, A.M. de Frias (1989). Espécies novas do género Oxychilus (Gastropoda: Zonitidae) na Ilha Terceira. Açoreana 7(1): 55-71.

Martins, A.M. de Frias (1991). Comparative anatomy of populations of Oxychilus (Drouetia) atlanticus (Morelet et Drouët, 1857) (Pulmonata: Zonitidae) from São Miguel island, Azores. Proceedings of the Tenth International Malacological Congress (Tuibingen, 1989): 571-575.

Martins, A.M. de Frias (1993). The Azores - westernmost Europe: where evolution can be caught red-handed. In: Hounsome, M.V. (ed.), Proceedings of Manchester N Atlanitic Islands Conference, September 1990. Boletim do Museu Municipal do Funchal, Suplemento $N^{\circ}$. 2: 181-198.

Martins, A.M. de Frias (1995). Volcanic eruptions and speciation in the Azores. In Guerra, A., Rolán, E. and Rocha, F. (eds), Abstracts of the Twelfth International Malacological Congress (Unitas Malacologica), p. 382. Feito, S.L., Vigo [Abstract].

Martins, A.M. de Frias (1998). Islands, Volcanoes and Species: colonization and speciation in the Açores Islands. Programa, Resumos e Participantes no III Simpósio Fauna e Flora das Ilhas Atlânticas, 21-25 Setembro, Ponta Delgada, p. 48 [Abstract].

Martins, A.M. de Frias (1999). Evolution and distribution of the terrestrial molluscs of the Açores. Bulletin of the Malacological Society of London 33: 5-6.

Martins, A.M. de Frias, Backeljau, T., Cunha, R.M. Tristão da and Brito, C.P. (1991). Moluscos Terrestres da llha de Santa Maria. Lista Preliminar. Relatórios e Comunicações do Departamento de Biologia. Santa Maria e Formigas/1990: Relatório Preliminar 19: 5359.

Mayr, E. (1977). Populations, Species and Evolution (6 $6^{\text {th }}$ printing). The Belknap Press of Harvard University Press, Cambridge, Massachusetts.
Moore, R.B. (1990). Volcanic geology and eruption frequency, São Miguel, Azores. Bulletin of Volcanology 52: $602-614$.

Moore, R.B. and Rubin, M. (1991). Radiocarbon dates for lava flows and pyroclastic deposits on São Miguel, Azores. Radiocarbon 33(1): 151-164.

Morelet, A. (1860). Notice sur l'Histoire Naturelle des Açores Suivie d'Une Description des Mollusques Terrestres de cet Archipel. J.-B. Baillière, Paris.

Morelet, A. and Drouët, H. (1857). Conchologiae Azoricae prodromus novarum specierum diagnoses sistens. Journal de Conchyliologie 6, $2^{\mathrm{e}}$ série, 2: 148-153.

Nunes, J.C., Carvalho, M.R. and Forjaz, V.H. (1993). Short note on S. Miguel Island (Azores) tiltmeters. Açoreana 7(4): 633-641.

Queiroz, G., Gaspar, J.L., Cole, P.D., Guest, J.E., Wallenstein, N., Duncan, A.M. and Pacheco, J. (1995). Erupções vulcânicas no Vale das Furnas (Ilha de S. Miguel, Açores) na primeira metade do século XV. Açoreana 8(1): 159-165.

Riedel, A. (1964). Zonitidae (Gastropoda) der Azoren. Boletim do Museu Municipal do Funchal 18(66): 5-60.

Riedel, A. (1997). The Zonitidae (sensu latu) on the southeastern and south-western borders of their Palaearctic distribution area (Gastropoda, Stylommatophora). Heldia 4(5): 98-100.

Serralheiro, A. and Madeira, J. (1993). Stratigraphy of Santa Maria island (Azores). Açoreana 7(4): 575-592.

Van Riel, P., Jordaens, K., Verhagen, R., Martins, AM de Frias and Backeljau, T. (2003). Genetic differentiation reflects geological history in the Azorean land snail, Leptaxis azorica. Heredity 91: 239-247.

Walker, J.P.L and R. Croasdale (1971). Two Plinian eruptions in the Azores. Journal of the Geological Society of London 127: 17-55.

Wiens, J.J. (2004). The role of morphological data in phylogeny reconstruction. Systematic Biology 53(4): 653-661.

Winter, A.J. de (1989). Remarks on the non-marine molluscan fauna of the Azores. 3. A new species of Drouetia from the Isle of São Miguel (Pulmonata: Zonitidae). Basteria 53: 63-67.

Zilch, A. (1959-1960). Gastropoda, Teil 2 - Euthyneura. In: O.H. Schindewolf, Handbuch der Paläozoologie, 6. Gebrüder Borntraeger, Berlin. 


\section{Guide to Authors}

\section{Subject Matter:}

Reviews, observations and results of research into all branches of natural science and human studies will be considered for publication. However, emphasis is placed on studies pertaining to Western Australia. Longer papers will be considered for publication as a Supplement to the Records of the Western Australian Museum. Short communications should not normally exceed three typed pages and this category of paper is intended to accommodate observations, results or new records of significance, that otherwise might not get into the literature, or for which there is a particular urgency for publication. All material must be original and not have been published elsewhere.

\section{Presentation:}

Authors are advised to follow the layout and style in the most recent issue of the Records of the Western Australian Museum including headings, tables, illustrations and references.

The title should be concise, informative and contain key words necessary for retrieval by modern searching techniques. An abridged title (not exceeding 50 letter spaces) should be included for use as a running head.

An abstract must be given in full length papers but not short communications, summarizing the scope of the work and principal findings. It should normally not exceed $2 \%$ of the paper and should be suitable for reprinting in reference periodicals.

The International System of units should be used.

Numbers should be spelled out from one to nine in descriptive text; figures used for 10 or more. For associated groups, figures should be used consistently, e.g. 5 to 10 , not five to 10 .

Spelling should follow the Concise Oxford Dictionary.

Systematic papers must conform with the International Codes of Botanical and Zoological Nomenclature and, as far as possible, with their recommendations.

Synonymies should be given in the short form (taxon, author, date, page) and the full reference cited at the end of the paper. All citations, including those associated with scientific names, must be included in the references.

\section{Manuscripts:}

The original and two copies of manuscripts and figures should be submitted to the Editors, c/Publications Department, Western Australian Museum, Francis Street, Perth, Western Australia 6000 . They must be in double-spaced typescript on A4 sheets. All margins should be at least $30 \mathrm{~mm}$ wide. Tables plus heading and legends to illustrations should be typed on separate pages: The desired position for insertion of tables and illustrations in the text should be indicated in pencil. Tables should be numbered consecutively, have headings which make them understandable without reference to the text, and be referred to in the text.

High quality illustrations are required to size $(16.8 \mathrm{~cm} \times 25.2 \mathrm{~cm})$ or no larger than $32 \mathrm{~cm} \times 40$ $\mathrm{cm}$ with sans serif lettering suitable for reduction to size. Photographs must be good quality black and white prints, not exceeding $16.8 \mathrm{~cm} \times 25.2 \mathrm{~cm}$. Scale must be indicated on illustrations. All maps, line drawings, photographs and graphs, should be numbered in sequence and referred to as Figure/s in the text and captions. Each must have a brief, fully explanatory caption. On acceptance a computer disk containing all corrections should be sent with amended manuscript. The disk should be marked with program (e.g. Word, WordPerfect, etc).

In papers dealing with historical subjects references may be cited as footnotes. In all other papers references must be cited in the text by author and date and all must be listed alphabetically at the end of the paper. The names of journals are to be given in full.

\section{Processing:}

Papers and short communications are reviewed by at least two referees and acceptance or rejection is then decided by the editors.

The senior author is sent one set of page proofs which must be returned promptly.

The senior author will receive fifty free offprints of the paper. Additional offprints can be ordered at page proof stage. 